\title{
Reassessment of Fungicide Synergism for Control of Dollar Spot
}

\author{
Lee Burpee, Department of Plant Pathology, University of Georgia, Griffin 30223; and Richard Latin, Department
} of Botany and Plant Pathology, Purdue University, West Lafayette, IN 47907

\begin{abstract}
Burpee, L., and Latin, R. 2008. Reassessment of fungicide synergism for control of dollar spot. Plant Dis. 92:601-606.

Experiments were designed to assess reports of synergism between propiconazole and other fungicides to control dollar spot in creeping bentgrass. In 2004 and 2006, two field experiments were conducted near Griffin, GA, and repeated near West Lafayette, IN. A third experiment was conducted at the Griffin site in 2007. In each experiment, replicated treatments of commercial formulations of propiconazole, triadimefon, iprodione, vinclozolin, and chlorothalonil were applied to plots of creeping bentgrass at the sublabel rates of $0.12,0.38,0.57,0.38$, and $2.29 \mathrm{~kg}$ a.i. ha ${ }^{-1}$, respectively. In addition, each of the latter four fungicides was tank mixed with propiconazole at the rates given, and applied as treatments. Plots were treated once in experiments 1 and 3 , and three times at a 21-day interval in experiment 2 . Nontreated plots served as controls. Disease intensity was assessed visually by estimating the area of each plot that exhibited dollar spot symptoms. Synergism between tank-mixed fungicides was determined by comparing actual and expected values of the duration of disease control (experiment 1) or the percentage of disease control (experiments 2 and 3 ) in treated plots. No synergistic interactions were detected at Griffin or West Lafayette in experiments 1 or 2. In the first trial of experiment 3, synergism was observed between propiconazole and iprodione on one of five ratings dates and between propiconazole and vinclozolin on two of five rating dates. However, no synergistic interactions were detected in the second trial. Results suggest that there is a low probability for turfgrass managers to take advantage of fungicide synergism to control dollar spot with the products and rates tested.
\end{abstract}

Pesticide synergism has been defined as "the simultaneous action of two or more compounds in which the total response of an organism to the pesticide combination is greater than the sum of the individual components" (19). In contrast, antagonism occurs when the response is smaller than the sum of the components. The observed response may be direct (e.g., insect or weed mortality; 3,14) or indirect (e.g., disease suppression 8,20,23). Theoretically, when fungicides interact synergistically, a high level of disease control is achieved with less than label rates of each component fungicide. More pronounced synergistic effects reportedly occur between fungicides with different modes of action, although synergy also has been described between certain fungicides with a similar mode of action (9). Many of the investigations that address synergy in fungicide mixtures have been limited to laboratory studies with cultures of fungal pathogens $(9,10,12)$. However, some published studies demonstrate synergistic interactions between fungicides at the field level $(8,23)$.

Corresponding author: L. Burpee
E-mail: lburpee@uga.edu

Accepted for publication 16 November 2007.

doi:10.1094/PDIS-92-4-0601

(C) 2008 The American Phytopathological Society
In determining synergism among fungicides in field plots, the expected level of control provided by the sum of the individual components is, by definition, an approximation and, therefore, can be determined only by calculation. There are several different approaches to calculating the expected effect of fungicide combinations, and most are appropriate only for laboratory studies (16). The Gowing (13) method is a simple calculation to estimate additive effects of two compounds in a mixture. It has been used to identify synergistic interactions among herbicides (13) and was applied similarly to fungicide combinations (8).

To our knowledge, reports of fungicide synergism on turfgrass diseases are limited to those of Couch (4-7) and Couch and Smith (8). In tests conducted on dollar spot of creeping bentgrass (Agrostis stolonifera L.) caused by Sclerotinia homoeocarpa F. T. Benn. (4-7) and Pythium blight of perennial ryegrass (Lolium perenne L.) caused by Pythium aphanidermatum (Edson) Fitzp. (8), interactions among fungicides were deemed synergistic, antagonistic, or additive based on a comparison of expected and actual levels of disease control. Results of the Pythium blight study were published in a refereed journal article (8). However, methods and results of the dollar spot studies were not published in detail (4-7). For example, fungicide names, rates of application, and synergistic tank-mix combinations were listed in each nonrefereed publication (4-7) but information related to the detection of synergism was incomplete and unclear.

To our knowledge, there are no reports that confirm or refute Couch's findings (47). In a preliminary study (unpublished), we failed to detect synergistic effects among the fungicide tank mixes recommended by Couch $(4,5)$ for preventive control of dollar spot. Results of further studies are presented here.

\section{MATERIALS AND METHODS}

Two field experiments were conducted in 2004 and 2006 at the turfgrass research facility associated with the University of Georgia near Griffin, GA and repeated at Purdue University's turfgrass research center near West Lafayette, IN. A third experiment, consisting of two trials, was conducted at the Griffin site in 2007. In each experiment, fungicides (Table 1) were applied to creeping bentgrass individually and in tank-mix combinations at rates (Tables $2-7$ ) equivalent to those provided by Couch $(4,5)$.

Griffin experiments. The first experiment was conducted from 30 April to 31 May 2004 on a 14-year-old sward of creeping bentgrass cv. Penncross. The turfgrass was established from seed in 1990 on a sand-based root zone, mowed to a height of $5 \mathrm{~mm}$ three times per week, and otherwise maintained as prescribed for bentgrass golf greens (1). Fungicide treatments (Table 2 ) were applied to plots ( 1 by $3 \mathrm{~m}$ ) arranged on the green in a randomized complete block design with four replicates. Treatments were applied only once (30 April) to avoid any curative effects that subsequent applications may have had on disease development. Treatments were applied in 8.1 liters of water per $100 \mathrm{~m}^{2}$

Table 1. Fungicides tested in synergism experiments

\begin{tabular}{lll}
\hline Fungicide & Commercial formulation & \multicolumn{1}{c}{ Manufacturer } \\
\hline Propiconazole & Banner Maxx 1.24ME & Syngenta, Greensboro, NC 27409 \\
Triadimefon & Bayleton 50WP & Bayer Environmental Science, Montvale, NJ 07645 \\
Iprodione & 26GT 2SC & Bayer Environmental Science, Montvale, NJ 07645 \\
Vinclozolin & Curalan 50WG & BASF Corporation, Research Triangle Park, NC 27709 \\
Chlorothalonil & Daconil Weather Stik 54F & Syngenta, Greensboro, NC 27409 \\
\hline
\end{tabular}


with a wheel-mounted, $\mathrm{CO}_{2}$-pressured boom sprayer equipped with TeeJet flat fan nozzles (EVS 8004). The treated turf was left undisturbed for $6 \mathrm{~h}$ to allow the treatments to dry on the foliage, and then inoculated with $S$. homoeocarpa (isolate SO84) by hand-dispersal of fungus- infested rye grain into the turf canopy at a rate of approximately $7 \mathrm{~g}$ of grain per square meter. The grain inoculum was prepared as described by Burpee and Goulty (2) for inoculum of Rhizoctonia solani. After inoculation, the plots received approximately $0.6 \mathrm{~cm}$ of overhead irriga- tion daily at $1800 \mathrm{~h}$ to ensure nightly foliar wetness for infection.

Visual estimates of disease severity using the Horsfall-Barratt rating scale (15) were made at daily intervals after the fungicide application. These values were used to determine the number of days between

Table 2. Assessment of synergism among fungicides applied preventively for control of dollar spot in creeping bentgrass near Griffin, GA in 2004w

\begin{tabular}{|c|c|c|c|c|c|}
\hline \multirow[b]{2}{*}{ Treatment } & \multirow[b]{2}{*}{$\operatorname{Rate}\left(k g \text { a.i. ha }{ }^{-1}\right)^{y}$} & \multicolumn{2}{|c|}{ DIS $^{\mathbf{x}}$} & \multicolumn{2}{|c|}{ Days to $5 \%$ disease } \\
\hline & & Actual & Expected $^{\mathrm{z}}$ & Actual & Expected $^{\mathrm{z}}$ \\
\hline Nontreated check & & $7.3 \mathrm{~d}$ & $\ldots$ & $12.5 \mathrm{~d}$ & $\ldots$ \\
\hline Propiconazole & 0.12 & $12.0 \mathrm{~b}$ & $\ldots$ & $17.8 \mathrm{c}$ & $\ldots$ \\
\hline Triadimefon & 0.38 & $12.0 \mathrm{~b}$ & $\ldots$ & $16.8 \mathrm{c}$ & $\ldots$ \\
\hline Iprodione & 0.57 & $8.8 \mathrm{c}$ & $\ldots$ & $12.8 \mathrm{~d}$ & $\ldots$ \\
\hline Vinclozolin & 0.38 & $9.5 \mathrm{c}$ & $\ldots$ & $13.8 \mathrm{~d}$ & $\ldots$ \\
\hline Chlorothalonil & 2.29 & $8.5 \mathrm{c}$ & $\ldots$ & $12.8 \mathrm{~d}$ & $\ldots$ \\
\hline Propiconazole + triadimefon & $0.12+0.38$ & $14.5 \mathrm{a}$ & $22.6 * * *$ & $22.5 \mathrm{a}$ & $31.5 * *$ \\
\hline Propiconazole + iprodione & $0.12+0.57$ & $12.0 \mathrm{~b}$ & $19.7 * * *$ & $16.0 \mathrm{c}$ & $28.2 * * *$ \\
\hline Propiconazole + vinclozolin & $0.12+0.38$ & $12.8 \mathrm{~b}$ & $20.4 * * *$ & $19.5 \mathrm{~b}$ & $29.1 * * *$ \\
\hline Propiconazole + chlorothalonil & $0.12+2.29$ & $10.8 \mathrm{~b}$ & $19.5 * * *$ & $16.5 \mathrm{c}$ & $28.3 * * *$ \\
\hline
\end{tabular}

${ }^{w}$ Within a column, values followed by the same letter are not significantly different at $\alpha=0.05$ according to the Scott-Knott cluster analysis procedure.

${ }^{\mathrm{x}}$ Time (days) from inoculation to visual detection of initial symptoms (DIS).

${ }^{\mathrm{y}}$ Equivalent to rates recommended by Couch $(4,5)$.

${ }^{\mathrm{z}}$ Determined from the formula $E=X+[Y(100-X)] / 100$, where $X=$ the actual parameter values in plots treated with one component of a tank mixture and $\mathrm{Y}$ $=$ the actual parameter values in plots treated with a second component of the same tank-mixture. According to a $t$ test, expected values followed by $* *$ and *** are statistically significant from actual values at $P<0.01$ and 0.001 , respectively.

Table 3. Assessment of synergism among fungicides applied preventively for control of dollar spot in creeping bentgrass near West Lafayette, IN in $2004^{\mathrm{w}}$

\begin{tabular}{|c|c|c|c|c|c|}
\hline \multirow[b]{2}{*}{ Treatment } & \multirow[b]{2}{*}{ Rate $\left(\mathrm{kg} \mathrm{a.i.} \mathrm{ha}^{-1}\right)^{\mathrm{y}}$} & \multicolumn{2}{|c|}{ DIS $^{x}$} & \multicolumn{2}{|c|}{ Days to $2 \%$ disease } \\
\hline & & Actual & Expected $^{\mathrm{z}}$ & Actual & Expected $^{\mathrm{z}}$ \\
\hline Nontreated check & & $10.0 \mathrm{~d}$ & $\ldots$ & $23.8 \mathrm{~d}$ & $\ldots$ \\
\hline Propiconazole & 0.12 & $19.8 \mathrm{~b}$ & $\ldots$ & $36.0 \mathrm{~b}$ & $\ldots$ \\
\hline Triadimefon & 0.38 & $22.0 \mathrm{~b}$ & $\ldots$ & $39.5 \mathrm{~b}$ & $\ldots$ \\
\hline Iprodione & 0.57 & $17.3 \mathrm{c}$ & $\ldots$ & $33.5 \mathrm{c}$ & $\ldots$ \\
\hline Vinclozolin & 0.38 & $16.3 \mathrm{c}$ & $\ldots$ & $31.0 \mathrm{c}$ & $\ldots$ \\
\hline Chlorothalonil & 2.29 & $12.8 \mathrm{~d}$ & $\ldots$ & $31.0 \mathrm{c}$ & $\ldots$ \\
\hline Propiconazole + triadimefon & $0.12+0.38$ & $29.5 \mathrm{a}$ & $37.4 *$ & $48.0 \mathrm{a}$ & $61.2 * *$ \\
\hline Propiconazole + iprodione & $0.12+0.57$ & $25.3 \mathrm{a}$ & 33.4NS & $39.5 \mathrm{~b}$ & $57.4 * *$ \\
\hline Propiconazole + vinclozolin & $0.12+0.38$ & $23.3 \mathrm{~b}$ & $32.6^{*}$ & $38.0 \mathrm{~b}$ & $55.8^{* *}$ \\
\hline Propiconazole + chlorothalonil & $0.12+2.29$ & $22.0 \mathrm{~b}$ & $29.9 \mathrm{NS}$ & $37.0 \mathrm{~b}$ & $55.8^{* *}$ \\
\hline
\end{tabular}

${ }^{\mathrm{w}}$ Within a column, values followed by the same letter are not significantly different at $\alpha=0.05$ according to the Scott-Knott cluster analysis procedure.

${ }^{x}$ Time (days) from inoculation to visual detection of initial symptoms (DIS).

${ }^{y}$ Equivalent to rates recommended by Couch $(4,5)$.

${ }^{\mathrm{z}}$ Determined from the formula $E=X+[Y(100-X)] / 100$, where $X=$ the actual parameter values in plots treated with one component of a tank mixture and $\mathrm{Y}$ $=$ the actual parameter values in plots treated with a second component of the same tank-mixture. According to a $t$ test, expected values followed by $* *$ and $* * *$ are statistically significant from actual values at $P<0.05$ and 0.01 , respectively; NS $=$ not significant.

Table 4. Assessment of synergism among fungicides applied preventively for control of dollar spot in creeping bentgrass near Griffin, GA in 2006

\begin{tabular}{|c|c|c|c|c|c|c|c|c|c|c|c|c|c|c|c|}
\hline \multirow[b]{3}{*}{ Treatment $^{\mathrm{x}}$} & \multirow[b]{3}{*}{ Rate $^{y}$} & \multicolumn{14}{|c|}{ Control $(\%)^{\mathrm{w}}$} \\
\hline & & \multicolumn{2}{|c|}{24 May } & \multicolumn{2}{|c|}{31 May } & \multicolumn{2}{|c|}{7 June } & \multicolumn{2}{|c|}{17 June } & \multicolumn{2}{|c|}{22 June } & \multicolumn{2}{|c|}{28 June } & \multicolumn{2}{|c|}{5 July } \\
\hline & & Act. & Exp. $^{\mathrm{z}}$ & Act. & Exp. $^{\mathrm{z}}$ & Act. & Exp. $^{z}$ & Act. & Exp. $^{\mathrm{z}}$ & Act. & Exp. $^{\mathrm{z}}$ & Act. & Exp. $^{\mathrm{z}}$ & Act. & Exp. $^{\mathrm{z}}$ \\
\hline Prop. & 0.12 & $75.0 \mathrm{a}$ & $\ldots$ & $78.2 \mathrm{~b}$ & $\ldots$ & $75.0 \mathrm{~b}$ & $\ldots$ & $82.8 \mathrm{a}$ & $\ldots$ & $71.9 \mathrm{a}$ & $\ldots$ & $56.3 \mathrm{a}$ & $\ldots$ & $31.3 \mathrm{a}$ & $\ldots$ \\
\hline Triad. & 0.38 & $87.5 \mathrm{a}$ & $\ldots$ & $78.2 \mathrm{~b}$ & $\ldots$ & $75.0 \mathrm{~b}$ & $\ldots$ & $76.6 \mathrm{a}$ & $\ldots$ & $56.3 \mathrm{~b}$ & $\ldots$ & $46.3 \mathrm{a}$ & $\ldots$ & $22.5 \mathrm{a}$ & $\ldots$ \\
\hline Ipro. & 0.57 & $68.8 \mathrm{a}$ & $\ldots$ & $78.2 \mathrm{~b}$ & $\ldots$ & $68.8 \mathrm{~b}$ & $\ldots$ & $65.6 \mathrm{~b}$ & $\ldots$ & $31.3 \mathrm{~b}$ & $\ldots$ & $42.5 \mathrm{a}$ & $\ldots$ & $10.0 \mathrm{a}$ & $\ldots$ \\
\hline Vin. & 0.38 & $81.3 \mathrm{a}$ & $\ldots$ & $68.8 \mathrm{~b}$ & $\ldots$ & $68.8 \mathrm{~b}$ & $\ldots$ & $65.6 \mathrm{~b}$ & $\ldots$ & $50.0 \mathrm{~b}$ & $\ldots$ & $31.3 \mathrm{a}$ & $\ldots$ & $17.5 \mathrm{a}$ & $\ldots$ \\
\hline Chlor. & 2.29 & $50.1 \mathrm{~b}$ & $\ldots$ & $25.0 \mathrm{c}$ & $\ldots$ & $25.0 \mathrm{c}$ & $\ldots$ & $43.8 \mathrm{c}$ & $\ldots$ & $25.0 \mathrm{~b}$ & $\ldots$ & $20.0 \mathrm{a}$ & $\ldots$ & $22.5 \mathrm{a}$ & $\ldots$ \\
\hline Prop. + triad. & $0.12+0.38$ & $87.5 \mathrm{a}$ & $96.9 *$ & $100.0 \mathrm{a}$ & 94.9NS & $87.5 \mathrm{a}$ & $91.8 \mathrm{NS}$ & $90.6 \mathrm{a}$ & 95.7NS & $81.3 \mathrm{a}$ & $90.6 \mathrm{NS}$ & $56.3 \mathrm{a}$ & $83.3 *$ & $38.8 \mathrm{a}$ & $49.8 \mathrm{NS}$ \\
\hline Prop. + ipro. & $0.12+0.57$ & $81.3 \mathrm{a}$ & $92.2 *$ & $81.3 \mathrm{~b}$ & $94.9^{*}$ & $87.5 \mathrm{a}$ & $90.6 \mathrm{NS}$ & $89.1 \mathrm{a}$ & $94.2 \mathrm{NS}$ & $81.3 \mathrm{a}$ & 84.4NS & $75.0 \mathrm{a}$ & $76.3 \mathrm{NS}$ & $38.8 \mathrm{a}$ & $32.8 \mathrm{NS}$ \\
\hline Prop. + vin. & $0.12+0.38$ & $87.5 \mathrm{a}$ & $95.3 *$ & $84.4 \mathrm{~b}$ & 93.0NS & $93.8 \mathrm{a}$ & 89.9NS & $87.5 \mathrm{a}$ & $93.6 \mathrm{NS}$ & $71.9 \mathrm{a}$ & 85.2NS & $38.8 \mathrm{a}$ & $62.4 \mathrm{NS}$ & $21.3 \mathrm{a}$ & $33.9 \mathrm{NS}$ \\
\hline Prop. + chlor. & $0.12+2.29$ & $75.0 \mathrm{a}$ & 87.5NS & $78.2 \mathrm{~b}$ & $82.8 \mathrm{NS}$ & $84.4 \mathrm{a}$ & 79.7NS & $84.4 \mathrm{a}$ & 89.9NS & $78.1 \mathrm{a}$ & 79.7NS & $63.8 \mathrm{a}$ & $60.8 \mathrm{NS}$ & $53.8 \mathrm{a}$ & $49.8 \mathrm{NS}$ \\
\hline
\end{tabular}

${ }^{\mathrm{w}}$ Act. $=$ actual and Exp. $=$ expected. Within a column, values followed by the same letter are not significantly different at $\alpha=0.05$ according to the ScottKnott cluster analysis procedure.

${ }^{\mathrm{x}}$ Application dates 25 April, 16 May, and 6 June. Prop. $=$ piconazole, Triad. $=$ triadimefon, Ipro. $=$ iprodione, Vin. $=$ Vinclozolin, and Chlor. $=$ chlorothalonil.

${ }^{y}$ Rate $\left(\mathrm{kg}\right.$ a.i. ha $\left.{ }^{-1}\right)$.

${ }^{\mathrm{z}}$ Determined from the formula $E=X+[Y(100-X)] / 100$, where $X=$ the percent control in plots treated with one component of a tank mixture and $Y=$ the percent control in plots treated with a second component of the same tank-mixture. According to a $t$ test, expected values followed by $*$ and $* *$ are statistically significant from actual values at $P<0.05$ and 0.01 , respectively; NS $=$ not significant. 
the application of fungicide or inoculum and the observation of initial dollar spot symptoms, as well as the number of days required to reach 5\% disease severity in each plot. Expected values of days to initial symptoms and days to $5 \%$ disease were calculated for each fungicide tankmix combination (Table 2) using the formula of Gowing (13): expected values $(E)$ $=X+[Y(100-X)] / 100$, where $X=$ actual days to initial symptoms or days to $5 \%$ disease for one component of a tank mixture and $Y=$ the actual value for the second component of the same tank mixture.

A second experiment was conducted from 25 April to 6 July 2006 on the same sward of creeping bentgrass used in 2004, but at a site approximately $10 \mathrm{~m}$ from where the first experiment was conducted. Treatments, application rates, experimental design, inoculation, and disease assessment methods were the same as those used in the first experiment. However, unlike the first experiment, treatments were applied three times at an interval of 21 days and estimates of disease severity were made every 5 to 10 days from 24 May through 5 July. Disease severity values were converted to percent disease control using the formula control $=[(W-Z) / W] \times$ 100 , where $W$ and $Z=$ disease severity in nontreated and treated plots, respectively.

The third experiment was conducted in 2007 from 19 April to 31 May and repeated between 15 May and 25 June on previously nontreated sites in the sward of creeping bentgrass used for experiments 1 and 2 at Griffin. Materials and methods were the same as those used in the first experiment (2004) (i.e., fungicide treatments were applied once). However, unlike the first experiment, disease severity values were converted to percent control as in the second experiment.

West Lafayette experiments. Experiments 1 and 2 were conducted in 2004 and 2006, respectively. Plots measuring 1 by 2 $\mathrm{m}$ were arranged in a randomized complete block design with four replications on a sward of creeping bentgrass (cv. Penn A4) maintained as a putting green on a sandbased root zone mix. The site was mowed 6 days per week at a height of $4 \mathrm{~mm}$. Fungicide treatments (Table 3) were applied with a customized boom sprayer equipped with three TeeJet flat fan nozzles (EVS $8004)$ that delivered 8.1 liters per $100 \mathrm{~m}^{2}$. Disease severity was assessed at regular intervals by visually estimating the percentage of symptomatic turf in each plot (18).

Experiment 1 was conducted from 11 May to 7 June 2004. Approximately $6 \mathrm{~h}$ after the fungicide applications, the experimental site was inoculated with a sorghum-seed culture of $S$. homoeocarpa (isolate 1169) by distributing five infested grains per square meter in each plot. The plots received approximately $0.6 \mathrm{~cm}$ of overhead irrigation at $1800 \mathrm{~h}$ to ensure adequate wetness duration for infection. Plots were inspected at 2- to 3-day intervals to record the first appearance of dollar spot symptoms. Once disease was established, disease percentage was estimated at 5- to 7-day intervals.

Experiment 2 was conducted on the same sward of Penn A4 creeping bentgrass. Dollar spot was allowed to develop naturally without the addition of prepared inoculum. Fungicides were applied on 17

Table 5. Assessment of synergism among fungicides applied preventively for control of dollar spot in creeping bentgrass near West Lafayette, IN in 2006

\begin{tabular}{|c|c|c|c|c|c|c|c|c|c|c|c|c|c|c|c|}
\hline \multirow[b]{3}{*}{ Treatment $^{x}$} & \multirow[b]{3}{*}{ Rate $^{y}$} & \multicolumn{14}{|c|}{ Control $(\%)^{\mathrm{w}}$} \\
\hline & & \multicolumn{2}{|c|}{30 May } & \multicolumn{2}{|c|}{6 June } & \multicolumn{2}{|c|}{19 June } & \multicolumn{2}{|c|}{21 June } & \multicolumn{2}{|c|}{27 June } & \multicolumn{2}{|c|}{10 July } & \multicolumn{2}{|c|}{19 July } \\
\hline & & Act. & Exp. $^{\text {z }}$ & Act. & Exp. $^{\mathrm{z}}$ & Act. & Exp. $^{z}$ & Act. & Exp. $^{z}$ & Act. & Exp. $^{z}$ & Act. & Exp. $^{\mathrm{z}}$ & Act. & Exp. $^{\mathrm{z}}$ \\
\hline Prop. & 0.12 & $46.8 \mathrm{a}$ & $\ldots$ & $82.7 \mathrm{a}$ & $\ldots$ & $76.0 \mathrm{a}$ & $\ldots$ & $82.3 \mathrm{a}$ & $\ldots$ & $91.4 \mathrm{a}$ & $\ldots$ & $86.2 \mathrm{a}$ & $\ldots$ & $55.3 \mathrm{a}$ & $\ldots$ \\
\hline Triad. & 0.38 & $63.5 \mathrm{a}$ & $\ldots$ & $92.3 \mathrm{a}$ & $\ldots$ & $94.7 \mathrm{a}$ & $\ldots$ & $94.8 \mathrm{a}$ & $\ldots$ & $97.2 \mathrm{a}$ & $\ldots$ & $95.2 \mathrm{a}$ & $\ldots$ & $81.4 \mathrm{a}$ & $\ldots$ \\
\hline Ipro. & 0.57 & $32.1 \mathrm{a}$ & $\ldots$ & $79.4 \mathrm{a}$ & $\ldots$ & $56.6 \mathrm{a}$ & $\ldots$ & $51.7 \mathrm{~b}$ & $\ldots$ & $74.1 \mathrm{c}$ & $\ldots$ & $78.2 \mathrm{~b}$ & $\ldots$ & $26.8 \mathrm{~b}$ & $\ldots$ \\
\hline Vin. & 0.38 & $38.3 \mathrm{a}$ & $\ldots$ & $59.7 \mathrm{~b}$ & $\ldots$ & $77.3 \mathrm{a}$ & $\ldots$ & $67.2 \mathrm{~b}$ & $\ldots$ & $86.3 \mathrm{~b}$ & $\ldots$ & $59.3 \mathrm{~b}$ & $\ldots$ & $20.5 \mathrm{~b}$ & $\ldots$ \\
\hline Chlor. & 2.29 & $20.5 \mathrm{a}$ & $\ldots$ & $54.3 \mathrm{~b}$ & $\ldots$ & $75.2 \mathrm{a}$ & $\ldots$ & $60.5 \mathrm{~b}$ & $\ldots$ & $80.1 \mathrm{c}$ & $\ldots$ & $88.3 \mathrm{a}$ & $\ldots$ & $20.5 \mathrm{~b}$ & $\ldots$ \\
\hline Prop. + triad. & $0.12+0.38$ & $45.0 \mathrm{a}$ & $65.0 \mathrm{NS}$ & $91.6 \mathrm{a}$ & $96.0 \mathrm{NS}$ & $94.9 \mathrm{a}$ & $91.0 \mathrm{NS}$ & $97.0 \mathrm{a}$ & 94.9NS & $98.6 \mathrm{a}$ & $99.2 \mathrm{NS}$ & $98.3 \mathrm{a}$ & $98.0 \mathrm{NS}$ & $90.4 \mathrm{a}$ & $87.1 \mathrm{NS}$ \\
\hline Prop. + ipro. & $0.12+0.57$ & $69.6 \mathrm{a}$ & $56.1 \mathrm{NS}$ & $82.4 \mathrm{a}$ & $95.9^{*}$ & $84.4 \mathrm{a}$ & 85.2NS & $82.7 \mathrm{a}$ & $91.4 \mathrm{NS}$ & $91.0 \mathrm{a}$ & $97.8 \mathrm{NS}$ & $92.5 \mathrm{a}$ & $96.2 \mathrm{NS}$ & $77.3 \mathrm{a}$ & $67.2 \mathrm{NS}$ \\
\hline Prop. + vin. & $0.12+0.38$ & $42.7 \mathrm{a}$ & 59.1NS & $89.3 \mathrm{a}$ & $91.4 \mathrm{NS}$ & $83.5 \mathrm{a}$ & $90.5 \mathrm{NS}$ & $90.5 \mathrm{a}$ & $93.8 \mathrm{NS}$ & $94.6 \mathrm{a}$ & 98.7NS & $95.7 \mathrm{a}$ & 92.4NS & $81.4 \mathrm{a}$ & $64.1 \mathrm{NS}$ \\
\hline Prop. + chlor. & $0.12+2.29$ & $57.5 \mathrm{a}$ & $54.2 \mathrm{NS}$ & 88.9 a & 91.1NS & 89.9 a & $94.1 \mathrm{NS}$ & $91.0 \mathrm{a}$ & 94.4NS & $96.4 \mathrm{a}$ & $98.5 \mathrm{NS}$ & $96.6 \mathrm{a}$ & 98.0NS & $61.6 \mathrm{a}$ & $64.1 \mathrm{NS}$ \\
\hline
\end{tabular}

${ }^{\mathrm{w}}$ Act. $=$ actual and Exp. $=$ expected. Within a column, values followed by the same letter are not significantly different at $\alpha=0.05$ according to the ScottKnott cluster analysis procedure.

${ }^{\mathrm{x}}$ Application dates 17 May, 1 June, and 21 June. Prop. $=$ piconazole, Triad. $=$ triadimefon, Ipro. = iprodione, Vin. = Vinclozolin, and Chlor. = chlorothalonil. y $\operatorname{Rate}\left(\mathrm{kg}\right.$ a.i. ha $\left.{ }^{-1}\right)$.

${ }^{\mathrm{z}}$ Determined from the formula $E=X+[Y(100-X)] / 100$, where $X=$ the percent control in plots treated with one component of a tank mixture and $Y=$ the percent control in plots treated with a second component of the same tank-mixture. According to a $t$ test, expected values followed by $*$ and $* *$ are statistically significant from actual values at $P<0.05$ and 0.01 , respectively; NS = not significant.

Table 6. Assessment of synergism among fungicides applied preventively for control of dollar spot in creeping bentgrass near Griffin, GA in 2007

\begin{tabular}{|c|c|c|c|c|c|c|c|c|c|c|c|}
\hline \multirow[b]{3}{*}{ Treatment $^{\mathbf{y}}$} & \multirow[b]{3}{*}{ Rate (kg a.i. ha $\left.{ }^{-1}\right)$} & \multicolumn{10}{|c|}{ Control $(\%)^{\mathbf{x}}$} \\
\hline & & \multicolumn{2}{|c|}{4 May } & \multicolumn{2}{|c|}{10 May } & \multicolumn{2}{|c|}{17 May } & \multicolumn{2}{|c|}{24 May } & \multicolumn{2}{|c|}{31 May } \\
\hline & & Act. & $\operatorname{Exp}^{z}$ & Act. & Exp. $^{\mathrm{z}}$ & Act. & Exp. $^{\mathrm{Z}}$ & Act. & Exp. $^{\mathrm{z}}$ & Act. & Exp. $^{\mathrm{z}}$ \\
\hline Prop. & 0.12 & $37.5 \mathrm{a}$ & $\ldots$ & $25.0 \mathrm{~b}$ & $\ldots$ & $18.8 \mathrm{~b}$ & $\ldots$ & $25.0 \mathrm{~b}$ & $\ldots$ & $31.3 \mathrm{~b}$ & $\cdots$ \\
\hline Triad. & 0.38 & $62.5 \mathrm{a}$ & $\ldots$ & $75.0 \mathrm{a}$ & $\ldots$ & $43.8 \mathrm{a}$ & $\ldots$ & $50.0 \mathrm{a}$ & . & $62.5 \mathrm{a}$ & $\ldots$ \\
\hline Ipro. & 0.57 & $50.0 \mathrm{a}$ & $\ldots$ & $37.5 \mathrm{~b}$ & $\ldots$ & $12.5 \mathrm{~b}$ & $\ldots$ & $12.5 \mathrm{~b}$ & $\ldots$ & $18.8 \mathrm{~b}$ & $\ldots$ \\
\hline Vin. & 0.38 & $87.5 \mathrm{a}$ & $\ldots$ & $25.0 \mathrm{~b}$ & $\ldots$ & $25.0 \mathrm{~b}$ & $\ldots$ & $12.5 \mathrm{~b}$ & $\ldots$ & $37.5 \mathrm{~b}$ & $\ldots$ \\
\hline Chlor. & 2.29 & $25.0 \mathrm{a}$ & $\ldots$ & $37.5 \mathrm{~b}$ & $\ldots$ & $12.5 \mathrm{~b}$ & $\ldots$ & $25.0 \mathrm{~b}$ & $\ldots$ & $31.3 \mathrm{~b}$ & $\ldots$ \\
\hline Prop. + Triad. & $0.12+0.38$ & $75.0 \mathrm{a}$ & $75.0 \mathrm{NS}$ & $87.5 \mathrm{a}$ & 81.3NS & $56.3 \mathrm{a}$ & 48.4NS & $56.3 \mathrm{a}$ & $62.5 \mathrm{NS}$ & $62.5 \mathrm{a}$ & $70.3 \mathrm{NS}$ \\
\hline Prop. + Ipro. & $0.12+0.57$ & $100.0 \mathrm{a}$ & $68.8^{* *}$ & $87.5 \mathrm{a}$ & $50.0 \mathrm{NS}$ & $56.3 \mathrm{a}$ & $21.9 \mathrm{NS}$ & $37.5 \mathrm{a}$ & $31.3 \mathrm{NS}$ & $62.5 \mathrm{a}$ & $36.0 \mathrm{NS}$ \\
\hline Prop. + Vin. & $0.12+0.38$ & $100.0 \mathrm{a}$ & $93.8 * *$ & $100.0 \mathrm{a}$ & $43.8 * *$ & $56.3 \mathrm{a}$ & $34.4 \mathrm{NS}$ & $50.0 \mathrm{a}$ & 31.3NS & $59.4 \mathrm{a}$ & $53.2 \mathrm{NS}$ \\
\hline Prop. + chlor. & $0.12+2.29$ & $75.0 \mathrm{a}$ & $43.8 \mathrm{NS}$ & $75.0 \mathrm{a}$ & $50.0 \mathrm{NS}$ & $37.5 \mathrm{a}$ & 21.9NS & $43.8 \mathrm{a}$ & $37.5 \mathrm{NS}$ & $50.0 \mathrm{a}$ & $48.5 \mathrm{NS}$ \\
\hline
\end{tabular}

${ }^{\mathrm{x}}$ Act. $=$ actual and Exp. $=$ expected. Within a column, values followed by the same letter are not significantly different at $\alpha=0.05$ according to the ScottKnott cluster analysis procedure.

y Application date 19 April 2007. Prop. = piconazole, Triad. $=$ triadimefon, Ipro. $=$ iprodione, Vin. $=$ Vinclozolin, and Chlor. $=$ chlorothalonil.

${ }^{\mathrm{z}}$ Determined from the formula $E=X+[Y(100-X)] / 100$, where $X=$ the percent control in plots treated with one component of a tank mixture and $Y=$ the percent control in plots treated with a second component of the same tank-mixture. According to a $t$ test, expected values followed by $*$ and $* *$ are statistically significant from actual values at $P<0.05$ and 0.01 , respectively; NS = not significant. 
May, 1 June, and 21 June. Disease severity was assessed at 5- to 7-day intervals through the course of the experiment.

Statistical analysis. Analyses of variance of disease control data and comparisons between actual and expected control values were performed by Statistical Analysis Software (SAS Institute Inc., Cary, NC) procedures. Means were statistically separated using the Scott-Knott cluster analysis procedure (20).

\section{RESULTS}

Experiment 1. The dollar spot epidemics differed between locations. Although estimates of days to initial symptoms (DIS) in control plots were similar at each site, approximately 7 days at Griffin and 10 days at West Lafayette, the subsequent epidemic developed more rapidly at Griffin (Tables 2 and 3). Approximately 13 days were required to reach a threshold of $5 \%$ disease severity at Griffin and 24 days were required to reach a threshold of $2 \%$ disease at West Lafayette.

At the Griffin site, estimates of DIS were significantly greater in plots treated with each fungicide or tank-mix combination compared with the nontreated control (Table 2). Results were similar at West Lafayette except that, in plots treated with chlorothalonil, actual DIS was not significantly different from the control (Table 3). Among the non-tank-mixed treatments at both sites, actual DIS was significantly greater in plots treated with the acropetal penetrant fungicides propiconazole or triadimefon compared with plots treated with localized penetrants (iprodione or vinclozolin) or the contact fungicide chlorothalonil. Compared with turf treated with propiconazole alone, actual DIS was significantly greater in plots treated with propiconazole + triadimefon at both locations (Tables 2 and 3) and in plots treated with propiconazole + iprodione at West Lafayette (Table 3).

No evidence of fungicide synergism was detected in experiment 1 at Griffin or West Lafayette. At Griffin, expected values of
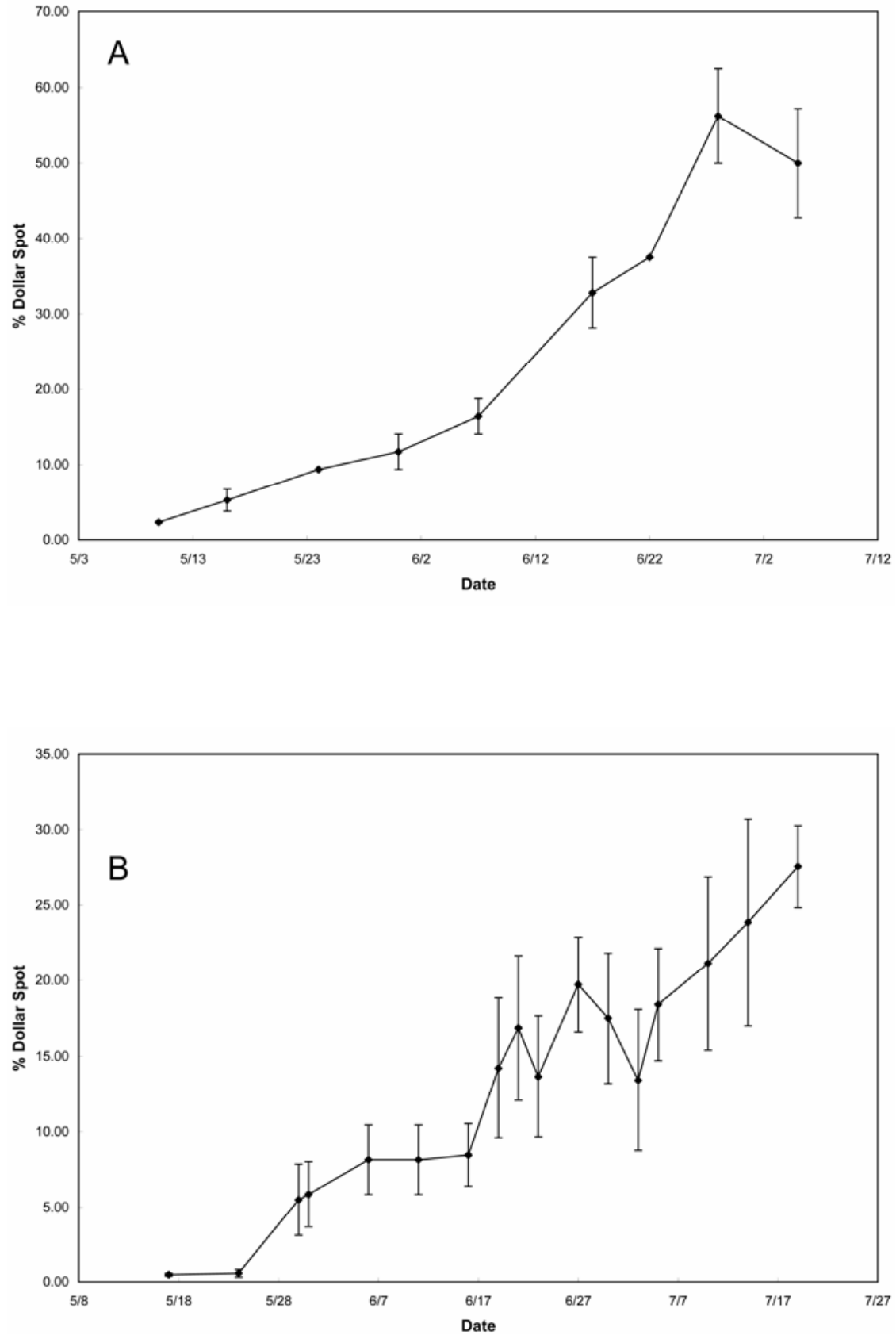

Fig. 1. Progression of dollar spot severity in nontreated plots of creeping bentgrass in experiment 2 at A, Griffin, GA and B, West Lafayette, IN.

Table 7. Assessment of synergism among fungicides applied preventively for control of dollar spot in creeping bentgrass near Griffin, GA in 2007

\begin{tabular}{|c|c|c|c|c|c|c|c|c|c|}
\hline \multirow[b]{3}{*}{ Treatment $^{\mathbf{y}}$} & \multirow[b]{3}{*}{ Rate (kg a.i. ha $\left.{ }^{-1}\right)$} & \multicolumn{8}{|c|}{ Control $(\%)^{x}$} \\
\hline & & \multicolumn{2}{|c|}{5 June } & \multicolumn{2}{|c|}{12 June } & \multicolumn{2}{|c|}{19 June } & \multicolumn{2}{|c|}{25 June } \\
\hline & & Actual & Expected $^{\mathrm{z}}$ & Actual & Expected $^{\mathrm{z}}$ & Actual & Expected $^{\mathrm{z}}$ & Actual & Expected $^{\mathrm{z}}$ \\
\hline Prop. & 0.12 & $50.0 \mathrm{a}$ & $\ldots$ & $43.8 \mathrm{a}$ & $\ldots$ & $12.5 \mathrm{~b}$ & $\ldots$ & $12.5 \mathrm{a}$ & .. \\
\hline Triad. & 0.38 & $75.0 \mathrm{a}$ & $\ldots$ & $68.8 \mathrm{a}$ & $\ldots$ & $56.3 \mathrm{a}$ & $\ldots$ & $37.5 \mathrm{a}$ & $\ldots$ \\
\hline Ipro. & 0.57 & $25.0 \mathrm{~b}$ & $\ldots$ & $37.5 \mathrm{a}$ & $\ldots$ & $25.0 \mathrm{~b}$ & $\ldots$ & $12.5 \mathrm{a}$ & $\ldots$ \\
\hline Vin. & 0.38 & $50.0 \mathrm{a}$ & $\ldots$ & $37.5 \mathrm{a}$ & $\ldots$ & $12.5 \mathrm{~b}$ & $\ldots$ & $37.5 \mathrm{a}$ & $\ldots$ \\
\hline Chlor. & 2.29 & $25.0 \mathrm{~b}$ & & $25.0 \mathrm{a}$ & $\ldots$ & $0.0 \mathrm{~b}$ & $\ldots$ & $12.5 \mathrm{a}$ & $\ldots$ \\
\hline Prop. + Triad. & $0.12+0.38$ & $75.0 \mathrm{a}$ & $87.5 \mathrm{NS}$ & $62.5 \mathrm{a}$ & $82.8 \mathrm{NS}$ & $56.3 \mathrm{a}$ & $62.5 \mathrm{NS}$ & $37.5 \mathrm{a}$ & $43.8 \mathrm{NS}$ \\
\hline Prop. + Ipro. & $0.12+0.57$ & $87.5 \mathrm{a}$ & $62.5 \mathrm{NS}$ & $50.0 \mathrm{a}$ & $65.7 \mathrm{NS}$ & $37.5 \mathrm{a}$ & $37.5 \mathrm{NS}$ & $25.0 \mathrm{a}$ & $25.0 \mathrm{NS}$ \\
\hline Prop. + Vin. & $0.12+0.38$ & $87.5 \mathrm{a}$ & $75.0 \mathrm{NS}$ & $25.0 \mathrm{a}$ & $65.7 \mathrm{NS}$ & $12.5 \mathrm{~b}$ & $25.0 \mathrm{NS}$ & $25.0 \mathrm{a}$ & $43.8 \mathrm{NS}$ \\
\hline Prop. + chlor. & $0.12+2.29$ & $75.0 \mathrm{a}$ & $62.5 \mathrm{NS}$ & $43.8 \mathrm{a}$ & $53.2 \mathrm{NS}$ & $25.0 \mathrm{~b}$ & $12.5 \mathrm{NS}$ & $25.0 \mathrm{a}$ & $25.0 \mathrm{NS}$ \\
\hline
\end{tabular}

${ }^{\mathrm{x}}$ Within a column, values followed by the same letter are not significantly different at $\alpha=0.05$ according to the Scott-Knott cluster analysis procedure.

y Application date 15 May 2007. Prop. = piconazole, Triad. = triadimefon, Ipro. = iprodione, Vin. $=$ Vinclozolin, and Chlor. $=$ chlorothalonil.

${ }^{\mathrm{z}}$ Determined from the formula $E=X+[Y(100-X)] / 100$, where $X=$ the percent control in plots treated with one component of a tank mixture and $Y=$ the percent control in plots treated with a second component of the same tank-mixture. According to a $t$ test, expected values followed by * and $* *$ are statistically significant from actual values at $P<0.05$ and 0.01 , respectively; NS $=$ not significant 
DIS were significantly greater than actual values, an indication of antagonism between fungicides, in plots treated with each of the tank mixes tested (Table 2). At West Lafayette, expected values of DIS were significantly greater than actual values in plots treated with propiconazole + triadimefon or propiconazole + vinclozolin (Table 3). Expected values of the number of days required to reach thresholds of $5 \%$ disease at Griffin or 2\% disease at West Lafayette were significantly greater than actual values in plots treated with each tank mix tested (Tables 2 and 3).

Experiment 2. At the Griffin location, dollar spot symptoms were detected initially on 10 May in nontreated control plots of creeping bentgrass. The epidemic in the nontreated plots progressed, reaching a peak disease intensity of approximately $57 \%$ by 28 June (Fig. 1A). No significant differences in disease control values were detected among treated plots prior to 24 May (data not shown). On the rating dates of 24 May through 17 June, percent disease control was significantly lower in plots treated with chlorothalonil alone compared with plots treated with the other fungicides or tank-mix combinations tested (Table 4). Significant differences in disease control among plots treated with propiconazole or triadimefon alone and plots treated with iprodione or vinclozolin alone were not detected until 17 and 22 June, 11 and 16 days after the final fungicide applications, respectively. By 28 June (22 days after the final applications), no significant differences in disease control were detected in plots treated with the individual fungicides or tank-mix combinations tested.

Among the fungicide tank mixes, dollar spot control provided by propiconazole + triadimefon was significantly greater than that provided by propiconazole alone on 31 May and 7 June (Table 4). Control provided by the remaining tank mixes was significantly greater than that provided by propiconazole alone on 7 June but not on the other rating dates.

No synergistic interactions were detected between tank-mix fungicides in experiment 2 at Griffin. Expected values of disease control were significantly greater than actual values, a sign of antagonism, on two rating dates (24 May and 28 June) in plots treated with propiconazole + iprodione and on one rating date (24 May) in plots treated with propiconazole + triadimefon or propiconazole + vinclozolin.

At West Lafayette, initial dollar spot symptoms were observed on 17 May. Disease intensity in the nontreated plots peaked at approximately $27 \%$ on 17 July (Fig. 1B). Data analysis was conducted from rating dates (Table 5) that were preceded by an increase in dollar spot intensity in the nontreated plots (Fig 1B). With the exception of 30 May and 19 June, significant differences in disease control val- ues were detected on the selected rating dates (Table 5). The tank-mixed treatments and the individual treatments of propiconzole and triadimefon provided significantly greater dollar spot control than iprodione, vinclozolin, or chlorothalonil on most rating dates after 30 May. Percent control values for the tank-mixed combinations were not significantly different from values associated with individual treatments of propiconazole or triadimefon on any of the rating dates. Likewise, no significant differences were detected among the tankmixed combinations.

No synergism was detected between fungicides in experiment 2 at West Lafayette. Antagonism was detected on 6 June, where actual disease control values were significantly lower than expected values in plots treated with propiconazole + iprodione (Table 5). All remaining comparisons between actual and expected control were not statistically significant.
Experiment 3. In trial 1, dollar spot symptoms initially were detected in nontreated plots on 27 April (Fig. 2A). Disease severity increased through the test period, reaching approximately $10 \%$ disease by the end of the trial. Significant differences among treatments were not detected until 10 May (Table 6). On this and subsequent rating dates, percent disease control was significantly greater in plots treated with triadimefon alone or the tank-mix combinations compared with plots treated with propiconazole, iprodione, vinclozolin, or chlorothalonil. No significant differences in disease control were detected among the fungicide tank mixes in trial 1 . However, actual levels of control were significantly greater than expected levels (an indication of synergism) in plots treated with propiconazole + iprodione on 4 May and with propiconazole + vinclozolin on 4 and 10 May.
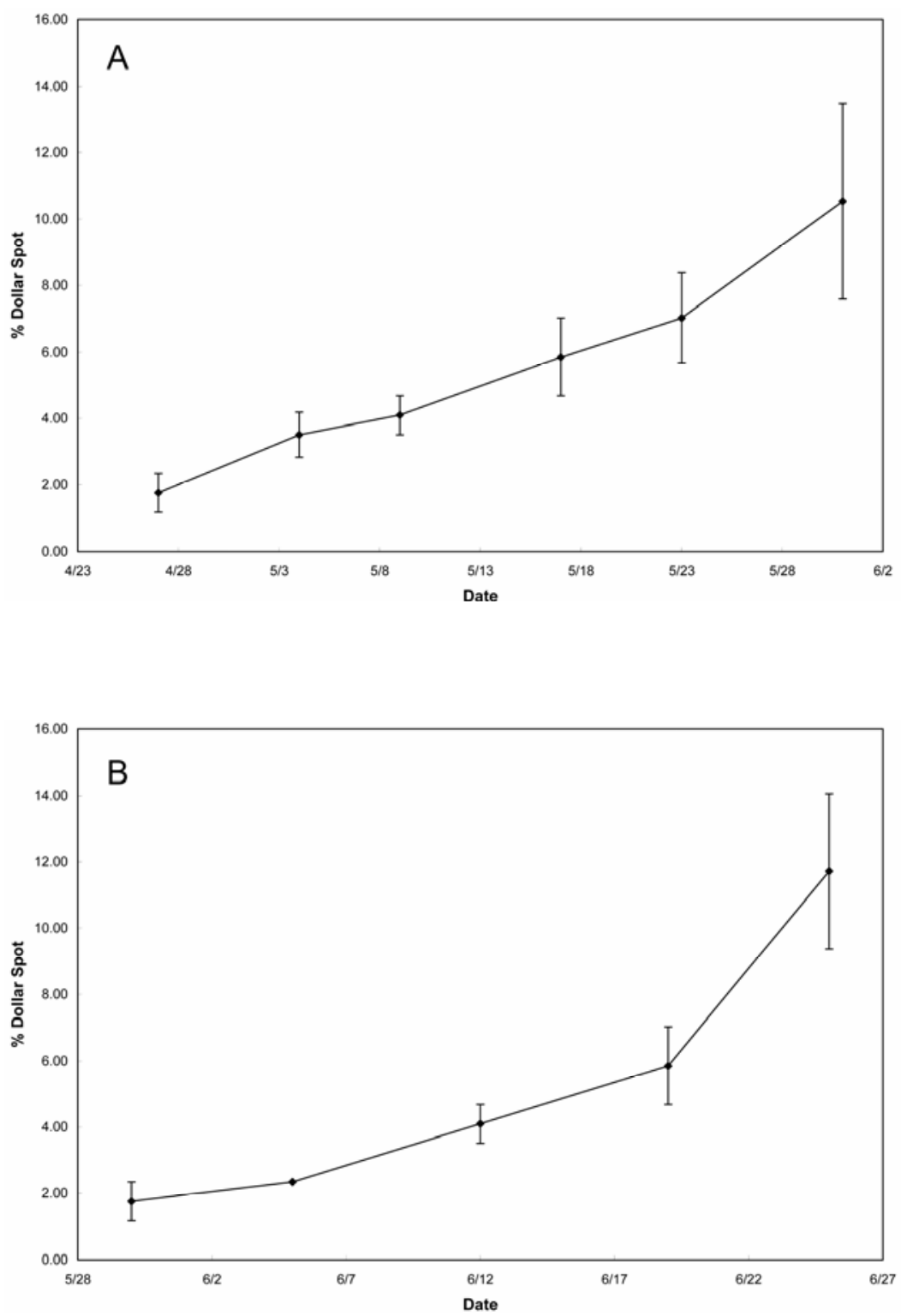

Fig. 2. Progression of dollar spot severity in nontreated plots of creeping bentgrass in experiment 3 at Griffin, GA. A, Trial 1. B, Trial 2. 
The dollar spot epidemic in nontreated plots in trial 2 (Fig. 2B) was similar to the epidemic in trial 1. Symptoms initially were detected on 30 May, followed by an increase in severity to a level of approximately $12 \%$ disease severity on 25 June. Significant differences among treatments were detected on two of the four rating dates (Table 7). On 5 June, disease control in plots treated with vinclozolin alone or chlorothalonil alone was significantly less than control provided by the other treatments tested. On 19 June, plots treated with triadimefon alone, propiconazole + triadimefon, or propiconazole + iprodione exhibited significantly greater disease control than plots treated with the other fungicides tested. No significant differences were detected between actual and expected control in trial 2.

\section{DISCUSSION}

Results of this study failed to provide consistent and reproducible evidence of fungicide synergism for control of dollar spot using recommended products and application rates (4-7). No synergistic interactions occurred at Griffin or West Lafayette in experiments 1 and 2. In trial 1 of experiment 3 at Griffin, synergism was detected between propiconazole and iprodione on one of five rating dates and between propiconazole and vinclozolin on two of five rating dates. However, these synergistic interactions were not evident when the experiment was repeated.

Failure to detect synergism may have resulted from the surprisingly low DIS and disease threshold values associated with treated plots in experiment 1 and the high levels of disease control $(>50 \%)$ provided by most of the individual fungicide treatments in experiment 2 . This was particularly true for plots treated with propiconazole, which was a component of each of the tank mixes. In his review of fungicide synergism, Gisi (11) states that "synergistic interactions always decrease rapidly with increasing control levels of the single components... and may be almost nil at high control levels." We believe that our results from experiment 2 support this statement (i.e., either recommended fungicide rates $[4,5]$ were too high or our 21day reapplication interval was too short to provide adequate control levels required to detect synergism). In contrast, findings from experiment 1, where extensive antagonism was detected, suggest that recommended rates $(4,5)$ are too low to foster synergism. This anomaly probably can be explained by the fact that a single application of treatments was applied in experiment 1 whereas multiple applications (three) were applied in experiment 2. Because the potential for residual fungistatic or fungicidal effects from previous applications cannot be ruled out in experiment 2 , we can assume that some residual effects did occur, making the application rates appear too high to detect synergism. Latin (17) showed that, at label rates, fungistatic effects of three fungicides used in this study (propiconazole, chlorothalonil, and iprodione) failed to extend beyond 21 days on S. homoeocarpa in creeping bentgrass. Because the rates used by Latin (17) were higher than the rates of the tank mixes used in our study, the probability of fungistatic effects extending to 21 days in experiment 2 is low. However, postinfection fungicidal or fungistatic effects that occur within the 21-day residual period and reduce secondary inoculum of $S$. homoeocarpa (mycelium from foliar lesions) cannot be ruled out. Post-infection treatment of apple trees with propiconazole, iprodione, or vinclozolin reduced the size of blossom lesions caused by Monilinia fructicola (G. Winter) Honey (22), suggesting that these fungicides can kill or suppress the growth of fungal hyphae in plant tissue.

The antagonism detected in experiment 1 indicates that, at the rates tested, single applications of the tank mixes produced less than additive disease suppressive effects. This probably is not an indication of chemical antagonism between the products in the tank mixes but a function of the Gowing formula (13), which was designed to accommodate proportional data (i.e., percent disease control). Antagonism was not detected in experiment 3 , where treatments were applied once, as in experiment 1 , and percent disease control estimates were used to test for synergism. Nevertheless, the data from experiment 1 provide evidence that the interactions between the fungicides tested were, at best, additive and not synergistic.

In trial 1 of experiment 3 , actual disease control was significantly greater than expected control (an indication of synergism) on one of five rating dates in plots treated with propiconazole + iprodione and on two of five rating dates in plots treated with propiconazole + vinclozolin. However, on these rating dates (3 and 10 May 2007), dollar spot symptoms had not developed in any of the replicated plots treated with the forenamed tank mixes. Therefore, the statistical significant differences between actual and expected control may have resulted more from a lack of variation in actual control $(100 \%$ control in all replicates) than from a synergistic interaction. No synergistic interactions were detected in trial 2.

Results of this study suggest that there is a low probability for turfgrass managers (e.g., golf course superintendents) to take advantage of fungicide synergism to control dollar spot using the products and rates previously reported (4-7). However, research on potential synergism between tank-mixed fungicides for control of dollar spot should continue. In contrast to this study, investigation of synergism between fungicides that, on their own, provide only marginal control of dollar spot (e.g., some strobilurin and dithiocarbamate fungicides) may be productive.

\section{LITERATURE CITED}

1. Beard, J. B. 2002. Turf Management for Golf Courses, 2nd ed. Ann Arbor Press, Chelsea, MI.

2. Burpee, L. L., and Goulty, L. G. 1984. Suppression of brown patch disease of creeping bentgrass by isolates of nonpathogenic Rhizoctonia spp. Phytopathology 74:692-694.

3. Corbel, V., Chandre, F., Darriet, F., Lardeux, F., and Hougard, J.-M. 2003. Synergism between permethrin and propoxur against Culex quinquefasciatus mosquito larvae. Med. Vet. Entomol. 17:158-164.

4. Couch, H. B. 1995. Diseases of Turfgrasses, 3rd ed. Krieger Publishing Co., Malabar, FL.

5. Couch, H. B. 2000. The Turfgrass Disease Handbook. Krieger Publishing Co., Malabar, FL.

6. Couch, H. B. 2002. Better dollar spot control with less fungicide. Golf Course Manage. 70(11):89-93.

7. Couch, H. B. 2003. Strategies for preventing and managing fungicide resistance. Golf Course Manage. 71(5):111-115.

8. Couch, H. B., and Smith, B. D. 1991. Synergistic and antagonistic interactions of fungicides against Pythium aphanidermatum on perennial ryegrass. Crop Prot. 10:386-390.

9. De Waard, M. A. 1996. Synergism and antagonism in fungicide mixtures containing sterol demethylation inhibitors. Phytopathology 86:1280-1283.

10. DeWaard, M., and Gisi, U. 1995. Synergism and antagonism in fungicides. Pages 565-578 in : Modern Selective Fungicides. H. Lyr, ed. Gustav Fischer Verlag, Jena, Germany.

11. Gisi, U. 1996. Synergistic interaction of fungicides in mixtures. Phytopathology 86:1273-1279.

12. Gisi, U., Binder, H., and Rimbach, E. 1985. Synergistic interactions of fungicides with different modes of action. Trans. Br. Mycol. Soc. 85:299-306.

13. Gowing, D. P. 1960. Comments on tests of herbicide mixtures. Weeds 8:379-391.

14. Horowitz, M., and Herlinger, G. 1973. Interactions between residual herbicides at low concentrations. Weed Res. 13:367-372.

15. Horsfall, J. G., and Cowling, E. B. 1978. Pathometry: the measurement of plant disease. Pages 119-136 in: Plant Disease: An Advanced Treatise. Vol. 2, How Disease Develops in Populations. J. G. Horsfall and E. B. Cowling, eds. Academic Press, New York.

16. Kosman, E., and Cohen, Y. 1996. Procedures for calculating and differentiating synergism and antagonism in action of fungicide mixtures. Phytopathology 86:1263-1272.

17. Latin, R. 2006. Residual efficacy of fungicides for control of dollar spot in creeping bentgrass. Plant Dis. 90:571-575.

18. McDuffee, D., Schoonveld, W., and Latin, R. 2007. A practical field guide for estimating dollar spot severity on golf course turf. (Abstr.) Phytopathology 97:S73.

19. Nash, R. G. 1981. Phytotoxic interaction studies-techniques for evaluation and presentation of results. Weed Sci. 29:147-155.

20. Samoucha, Y., and Cohen, Y. 1984. Synergy between metalaxyl and mancozeb in controlling downy mildew in cucumbers. Phytopathology 74:1434-1437.

21. Scott, A. J., and Knott, M. 1974. A cluster analysis method for grouping means in the analysis of variance. Biometrics 30:507-512.

22. Wilcox, W. F. 1990. Postinfection and antisporulant activities of selected fungicides in control of blossom blight of sour cherry caused by Monilinia fructicola. Plant Dis. 74:808-811.

23. Zeun, H., and Buchenauer, H. 1991. Synergistic interactions of the fungicide mixture pyrazaphos-propiconazole against barley powdery mildew. J. Plant Dis. 98:526-538. 